\title{
Explaining Brazil as a rising state, 2003-2014: the role of policy diffusion as an international regulatory instrument
}

\author{
Henrique Menezes ${ }^{1} \cdot$ Marco Vieira $^{1}$
}

Published online: 22 May 2021

○) Springer Nature Limited 2021

\begin{abstract}
In this paper, we examine Brazil's international activism and ascent to the status of rising state during the presidencies of Luiz Inácio Lula da Silva (2003-2010) and his chosen successor, Dilma Rousseff (2011-2014). We focus on the dissemination of social policies under an innovative model of development that reflected the political and economic context of a developing country. We argue that this activism was framed in terms of Brazil's socio-economic and cultural peculiarities, whereby these were treated not as obstacles but as positive contributions to developing states' attempts to reform global governance structures. We argue that this reflects an alternative form of foreign policy politicisation in which the social dilemmas, particularities and contradictions of the Brazilian experience are incorporated in the foreign policy agenda to leverage its international stature as a rising state. We explain how Brazil's international cooperation through transferring its public policies and development models (policies for fighting hunger and poverty, agrarian development and income generation) to its Southern partners has been discursively articulated as representing Brazil's normative potential to contribute to political and institutional solutions, and rebuild norms and standards that affect the distribution of international power and wealth.
\end{abstract}

Keywords Brazil · International development $\cdot$ International norms $\cdot$ Policy diffusion $\cdot$ Policy transfer $\cdot$ Rising states

Henrique Menezes

hzmenezes@ccsa.ufpb.br

Marco Vieira

m.a.vieira@bham.ac.uk

1 Departamento de Relações Internacionais, Universidade Federal da Paraíba, João Pessoa/PB, Brazil 


\section{Introduction}

In recent years, Brazil has distinguished itself by playing a more active global role. This protagonism manifested itself most forcefully during the presidencies of Luiz Inácio Lula da Silva (2003-2010) and his successor, Dilma Rousseff (2011-2014). ${ }^{1}$ This interpretation is supported by: (i) Brazil's active participation in critical multilateral negotiations, especially on trade ${ }^{2}$ and climate change; (ii) its participation in important alliances and strategic coalitions with global implications, such as IBSA and BRICS; ${ }^{3}$ (iii) its efforts to broaden its diplomatic and commercial insertion, without undermining its relations with its traditional partners in the developed world; ${ }^{4}$ (iv) the expansion of regional integration initiatives, and the deepening of institutional arrangements in the region; ${ }^{5}$ (v) the demands for the reform of traditional international organisations such as the UN Security Council and the International Monetary Fund (IMF); and (vi) Brazil's self-presentation as a mediator of global conflicts and the international financial crisis.

The strengthening of its solidarity with the 'Global South' via closer relations with its neighbours as well as various African countries, plus the formation of blocs and coalitions with other developing countries, formed an essential part of the Brazilian strategy. Enhanced trade and public and private investment flows, especially through the Brazilian Development Bank (BNDES), were another central feature of Brazil's relations with its Southern partners. Moreover, throughout this period, Brazil dramatically increased its technical cooperation and assistance to other developing countries, expanding areas of assistance to health, education, food and nutritional security and social assistance, and greatly increasing its expenditure on international cooperation.

\footnotetext{
1 This article deals specifically with Lula's two administrations (2003-2006 and 2007-2010), and Rousseff's first term in office (2011-2014). It is important to highlight that there are significant differences between Lula's foreign policy activism and Rousseff's muted interest in foreign policy issues which led to a noticeable decrease in Brazil's diplomatic assertiveness under her administration. However, the direction and vision of Brazil as a normative leader in the Global South remained unaltered in both administrations. This was not the case, however, following her impeachment in 2016 when her successor, Michel Temer, undertook profound changes in the direction of Brazilian foreign policy. And nowadays, with the presidency of Jair Bolsonaro, the differences are even more acute, with Brazil almost becoming a pariah state.

2 The creation of the G20 for agricultural negotiations during the 2003 Cancún Ministerial is still a significant milestone for Brazilian foreign policy.

3 The BRICS have considerably expanded intra-group cooperation and sought to act to collectively influence international governance frameworks. However, in this article we will not address the BRICS specifically. On the role of the BRICS, see for example Stephen (2014), Nayyar (2016), Nel (2014). In spite of the implications of our argument for broader debates on rising powers and their coalitions, including BRICS, we focus here on Brazilian foreign policy and its normative impact through the diffusion and transfer of public policies as a regulatory instrument.

4 Brazil has significantly increased the number of diplomatic and trade missions in Africa, Asia, and Latin America.

5 In 2008 the Union of South American Nations was created followed two years later by the creation of the Community of Latin American and Caribbean States-both with a strong support of the Brazilian government.
} 
Brazil's international activism and its attempts to expand its strategic relations with 'non-central' countries and the international periphery were not unprecedented. Brazilian diplomacy had also played active, and sometimes dissident, global roles in other periods, and its strategic South-South approach had also previously defined the country's international agenda. This raises the question of whether the seemingly innovative approach to foreign relations introduced by Lula was really all that new. In response, we argue that the period in question was set apart by Brazil's efforts to play an active role in reshaping international norms and institutions, especially in the field of international development, but also by promoting and funding some new international arrangements focused on global social development. It can be said that Brazil has positioned itself internationally as a norm-maker and not just as a norm-taker.

In this sense, in this article we refer to Brazil as a rising state in terms of its unprecedented activism while proposing alternative normative and governance models to the organisation of international relations that responded to and reflected some demands of the periphery. It presented a positive interpretation of Brazil's status and capacities, notably its innovative socioeconomic development model, and externalised it as a way to influence international norms related to economic and social development. As a result, Brazil rose to play a significant role in the vocalisation of solutions for global problems and, even more importantly, disseminated this new approach through the diffusion and transfer of public policies and development models that provided a new governance framework for international cooperation. More specifically, Brazil utilised international cooperation to promote the diffusion and transfer of the developmental model adopted by the Workers' Party governments and to consolidate this by reframing some international organisation policies, as well as structuring some international mechanisms that encapsulate this particular perspective on how to deal with the development problems of the periphery.

In this paper, we analyse the process of emergence and consolidation of norms and international standards of behaviour, highlighting a less recurrent dimensionthe role of rising states in this process. As such, the article focuses on the role of Brazil as a result of its proactive foreign policy agenda. We claim that the status of Brazil as a rising state, while having no significant material capabilities, is justified in terms of its role as a global rule-maker. It is undoubtedly the case that Brazil experienced a period of strong economic growth between 2000 and 2013 (with the notable exception of 2009) - and the global demand for commodities is responsible for part of this growth. However, we argue in this paper that it was not the only factor explaining Brazil's rising international status, despite being a relevant one. One of the underlying assumptions of our argument, supported in well-established segments of the international relations literature, is that economic power is not necessarily a pre-condition for political influence while shaping the normative agenda of multilateral institutions (Jackson 1993; Goldstein and Keohane 1993; Diez 2005). One of our paper's main contributions is precisely to highlight the role of ideational elements of Brazil's policy agenda as an important driving force in Brazil's increased influence during this period. We claim that economic growth was one of the driving forces (but not a determinant) of the Brazilian political choices and public policies during this period. At other times in history, Brazil experienced even 
greater economic growth and did not implement policies nor engaged in sustained international campaigning for social development, income transfer and reduction of inequalities.

The novelty of Brazil's development strategy during the Workers' Party's administration and the central point we put forth in the article is the centrality given to social policies as an instrument for economic development and the attempt to embed these ideas in international normative frameworks. Brazilian hard power alone cannot explain Brazil's rising status. Instead, we argue that the country's self-assigned role as an example of successful implementation of innovative development policies was effectively deployed as a foreign policy instrument in international development debates.

What differentiates Brazil at that historical moment from its own past experiences is the construction of a development model that sought to unite wealth creation and the reduction of social inequalities - in reality, social development was an engine for national development and not merely welfare or compensatory policies. And despite Brazil having reached the sixth position among the richest countries in the world in 2012, the country never had the economic and material conditions to act directly and aggressively in international politics, due to its military deficits and budget constraints. So, the resources derived from economic growth were transformed into political innovations and channelled to the implementation and dissemination of good practices, collaborative initiatives and the sharing of successful public policy experiences.

In this sense, Brazil's emergence as a rising state cannot be explained exclusively in terms of a materialist analysis of its foreign policy imperatives, in which the conduct of states is seen as motivated by national strategic interests, or the interests of powerful domestic interest groups. According to our viewpoint, foreign policy motivations and incentives also involve the pursuit of non-material benefits, which are grounded in the idea that states strive for status recognition through moral leadership without necessarily expecting short-term material/political paybacks.

This interpretation is grounded in the role of socio-political factors, political culture and ideational motivations that influence political formulations and country strategies. In a seminal study, Karl Holsti (1970) pointed to the relevance of ideational elements, such as national values and ideology, while systematically examining 'national role conceptions' in shaping states' behaviour in international systems. ${ }^{6}$ In line with Hosti's approach, we argue that it is appropriate to analyse Brazilian activism and rising state status in relation to the dissemination, acceptance, and institutionalisation of practices that mirror Brazilian political elites' national role conceptions, in terms of development, and their understanding of policy solutions more suited to the political and economic contexts of developing countries. This activism reflects the social, cultural, and cognitive peculiarities of the country-or one particular interpretation of these elements - that are understood not as an obstacle for its development and international insertion, but as potential. It also reflects another form of the politicisation of foreign policy, in which the social dilemmas,

\footnotetext{
${ }^{6}$ For an important contemporary reference on role conception and theory in international relations, see, for example, Breuning (2011).
} 
particularities and contradictions of Brazilian modernisation and development reach the construction of the foreign policy agenda.

As shown later, Brazil's conception of international development problems is reflected in its efforts to transfer its development models and social policies through technical cooperation to its Southern partners (including those aimed at fighting poverty and hunger, and promoting agrarian development and income generation), and to disseminate its practices through international organisations. In addition, they reflect Brazil's self-identification as a country capable of contributing to the institutions governing and regulating the global order and helping to reform the norms and standards that influence the distribution of global wealth.

We engage with the relevant theoretical literature which claims that the transfer and diffusion of public policies are also forms of international socialisation, working to construct a shared understanding of problems and their solutions, and leading to new patterns of behaviour and the construction of new international governance mechanisms. However, the literature on policy diffusion and policy transfer pays scant attention to the processes in which non-central countries are the main actors, in the same sense that international relations theories struggle to explain the role of these countries in the construction of international norms. We demonstrate how certain successful social experiences in Brazil have been transferred and diffused in various ways, leading to the internationalisation and socialisation of a 'world view' and social development project supported by Brazil's credentials.

The argument proceeds in three parts: in the next section, we engage with the debate on the role of policy diffusion and policy transfer as a particular instrument for rising states to build norms and collective understandings on particular international problems. This is followed by an examination of the sources of Brazilian power that lead it to the position of a rising state-i.e. its social and economic development model, capable of responding to some international marginalised demands, consolidating itself as a new global benchmark. Finally, we analyse Brazil's role through the policy diffusion and transfer in developing new international norms and understandings regarding the economic and social development as well as working for the construction of specific governance mechanisms for this.

\section{Diffusion and transfer of public policies as rising states instrument for building international norms}

The strategic interaction between 'great powers' and rising states, emerging states, or emerging powers is a prominent feature of international relations. ${ }^{7}$ The emergence and consolidation of new imperial or hegemonic powers and the establishment of

\footnotetext{
7 We use the term rising states because it brings a broader interpretation to the political, economic, cultural, or social ascendancy of some countries, and is not limited to definitions based on traditional notions of power. Gardini clearly expresses this concern: 'Traditional categories based on classic notions of power have demonstrated their limitations to capture the international status of countries, especially of those rising states whose behaviour is substantially different from the assertive and dominant posture of established great powers' (Gardini 2016: 13).
} 
international norms and institutions that respond to these new power configurations are key areas of interest for International Relations scholars. The relationship between the centre and the periphery, and the normative structures that regulate them, affect the global distribution of wealth and power, and establish hierarchical relations among states. As a result, rising states, which tend to be materially disadvantaged and socially marginalised, will probably challenge the international order using different strategies and different sources of power (Murphy 2005; Stephen 2014; Towns 2012).

In this sense, the norms regulating the behaviour of states-including forms of interaction between states and the market, adequate development strategies, and acceptable social standards - are continually contested on the grounds that they produce non-symmetrical results, favouring some countries at the expense of others. International institutions establish patterns of production, commercialisation, and the distribution of wealth, and also develop normative frameworks or moral orders which tend to reinforce those patterns. In doing so, they create material and social hierarchies between the acceptable and unacceptable, the fair and the unfair, what hedge the capacity of action of those dissatisfied countries. ${ }^{8}$

In this setting, the asymmetrical distribution of wealth and the hierarchisation of social practices prompt the emergence of new forms of cooperation among peripheral states, and the emergence of new leaders will consequently lead to normative conflicts. Towns (2012) argues that these 'conflicts of interest' encourage the development of new norms on the margins of international society which can spread to the centre. Rising states demand international norms that are better suited to their social and economic interests, and give them a greater decision-making power within the mechanisms of international governance, thereby countering perceptions of being 'marginalised' and 'discredited'. A major feature of the campaign of Southern countries is a battle for recognition-a struggle against discrimination, disrespect and humiliation, and for recognition as equal members of international society capable of making autonomous political and economic decisions (Nel 2010). ${ }^{9}$

International politics is a space for the emergence and re-emergence of norms that allow rising states to demand new forms of political organisation and the recognition of new paths and tools for development. So, while creating and confirming accepted standards and homogenising behaviours, the social hierarchy established by international norms stimulates the development of alternative norms on the margins of the international system, which eventually begin to compete in material and discursive terms with the globally dominant ones. As their capacities for resource

\footnotetext{
${ }^{8}$ Once they establish what is normal and what is acceptable, and so what is abnormal and unacceptable behavior, thus creating standards to rank and classify states according to those models. In this sense, the formal observance and compliance mechanisms, as well as the definition of acceptable behaviours, limit state freedom and also produce asymmetrical results and distributive conflicts (Abbott and Snidal 1998).

9 As pointed by Nel (2010) the notion of recognition has gained currency in International Relations debates. The role of subjectivity and identity in explaining the role of countries is critical to understand the notions of inclusion, marginalisation etc. In the same sense, some postcolonial approaches have sought to explain the effects of years of colonisation and the material and moral exploitation of colonies in how they are viewed and treated today.
} 
mobilisation and engagement increase, but their development problems remain 'neglected' or 'delegitimised', rising states tend to present themselves as potential reformers of international institutions (Vieira 2012). The 'exportation' of public policies and development models that differ from those defined by the current world economic order provides a way for rising states to present themselves as normative actors. Put differently, the construction of political solutions for the developing societies' problems, which manifest themselves in particular policies and specific forms of sociability and identities, can be internationally socialised (Xiaoyu 2012).

To understand the role of rising states in building international norms, it is important to consider the role of policy diffusion and policy transfer and their impact on reconstruction of international governance. The recognition that specific policies represent common interests and their implementation are the best way of solving certain shared problems would lead to a broader understanding of appropriate behaviour and practices conforming to shared norms. As Towns explains, 'states come to adopt similar policies across the world because of the spread of new standards of behavior and new expectations about what states are supposed to do' (Towns 2012: 186), but also because they develop new solutions for their own problems.

While studies of policy diffusion and policy transfer encompass a wide-ranging of questions and problems, they tend to focus on how established norms affect the processes of diffusion and transfer, rather than the processes of building new international norms by the socialisation of practical solutions and interpretations of the adequate responses to prevailing problems. This is because they generally emphasise cases of policy transfer among developed countries or from developed countries to the Global South in which hierarchical and power relations are more clearly manifested and the rules that define the standards of conduct are ingrained. ${ }^{10}$ This leaves a gap in the literature about policy diffusion and transfer from and among Southern countries.

To analyse how policy diffusion and policy transfer can be used as international regulatory instruments, and the way in which Brazil sought to export its practices and policies, it is necessary to discuss briefly what does diffuse and transfer mean. Despite various interpretations of policy transfer and policy diffusion, scholars essentially analyse the same processes and phenomena. In general, they seek to understand 'the process in which knowledge about policies, administrative arrangements, institutions and ideas in one political setting (past or present) is used in the development of policies, administrative arrangements, institutions and ideas in another political setting' (Dolowitz and Marsh 2000: 5). They also consider the motives of a given country for adopting a policy or policies originally implemented in another one, especially when there is no clear relationship between the receiving country and the policy in question (Holzinger and Knill 2005).

These debates originate from a historical finding, namely the existence of a global process of policy convergence in terms of which policies, laws, and institutions have

\footnotetext{
10 As Morin and Gold (2015) explain, it is likely that the originator country will initiate the transplantation process through coercion, precisely because of conflicting interests between the parties.
} 
been replicated over time in different parts of the world (Drezner 2001). Political and institutional convergence occurs for various reasons and via many mechanisms, and countries embark on this kind of process in many different ways. It is, however, important to differentiate between the concepts of diffusion and transfer (Marsh and Sharman 2009).

Diffusion theorists seek to understand the standards of policy spread and argue that the policy choices made by any country are invariably shaped by those of others. Thus, diffusion refers to a less 'political' and more structural process in which ideas and policies spread geographically over time because of their perceived effectiveness, and policy replication by different countries is typically explained in terms of systemic variables inherent in globalisation, interdependence, and changes in communication technologies. In this view, country decisions are largely shaped by external and systemic pressures - diplomacy, market forces, pressures from transnational civil society, and the flows of ideas. These analyses of the spread of policies and ideas focus on identifying similar policies and producing general explanations of the causes, but do not examine the political processes that may affect a given policy choice (Marsh and Sharman 2009).

By contrast, studies of policy transfers emphasise the political processes that give rise to policy spread. That is, they address the 'negotiated' elements of the process, highlighting the role of agency and agents. Generally, in this view, actions which affect the transfer of policies are those that change ideas about or incentives for the adoption of a policy. This approach creates a wide spectrum of possibilities. At the one extreme, there is coercion- a form of action that clearly alters the incentives for a country to adopt a given policy. At the other, there are voluntary actions, where changes in ideas about and understandings of a given policy explain their adoption by another country. This fundamental distinction can encompass all forms and modalities of policy transfer (Dobbin, Simmons and Garreth 2007).

Regulatory competition and political imposition are typical ways in which decisions in a given country directly affect the incentives for another to adopt a given policy. In this perspective, countries are forced to adopt or adhere to certain policies and institutions by economic competition; economic coercion, through the manipulation of economic costs and benefits; or even military imposition (Elkins, Guzman and Simmons 2006). Learning and emulation are the most likely types of policy transfer in which changes in ideas explain the decision. Learning is directly related to how states and policymakers appropriate the policy experiences of others-these are rational decisions based on technical information, and positive narratives about the efficacy of a given policy developed in another country. Specifically, there may be direct support from the country originating the policy, through exchange of information and technical cooperation.

Therefore, it is important to note that states are persuaded to adopted policies by non-material structures, shared ideas, and intersubjective understandings, and not just material and economic ones. Norms and standards establish patterns of behaviour that change the expectations of states. At this point, a crucial question emerges: how do norms, public policies and practices diffuse among nations in the absence of material or coercive factors? Is this a natural process (inherent to political relations and the construction of discursive and identity ties), or is there some political 
manipulation? Therefore, understanding how policies are socially accepted is key to understanding how they spread.

Socialisation leads to the diffusion of norms, as well as to their consolidation through internalisation and repetition (Xiaoyu 2012). Those who adopt policies (or are willing to adopt them) do so because they believe in and accept the role and relevance of the policy in question. As noted previously, analyses of the diffusion and transfer of policies generally focus on flows from North to South (Landolt 2004). Recently, studies of policies diffusion and socialisation among Southern countries have increased as a result of the increase of technical cooperation among them.

In the next section, we argue that, in the period under review, Brazil's development and projection of a reformed international identity, combined with a relative increase in economic power significantly enhanced its normative capacity and ability to propose new solutions for global developmental problems. We will address the role of Brazil as a rising state and a rule-maker, examining its efforts to use diffusion of its social development model and transfer of some important public policies as a normative global instrument - that is, through the creation of incentives for the reproduction of some policies and the socialisation of a particular conception of socioeconomic development.

We will present some Brazilian initiatives to transfer and diffuse important public policies through technical cooperation. Insofar, as Brazilian policies spread globally and are transferred to their partners, they gain legitimacy. A consequence of this process is the institutionalisation of these practices by the reform of some practices of international organisations and the creation of new cooperative arrangements. In the next section, we will analyze the Brazilian development model in the period in question and the public policies that put this model to work and were transferred; and then analyze its efforts to build international norms and institutions that were responsive to the demands of the periphery.

\section{Brazil as a rising state: the normative power of social development}

Characterising Brazil as a rising state is not new. In general, analyses along these lines focus on Brazil's capabilities and performance in terms of measurable indicators of power (Kahler 2013). However, these variables do not fully explain the meaning and strength of Brazil's international insertion. According to Andrew Hurrell (2010), interpretations of Brazil's international role based on material factors are limited in two main ways. Any reading of social power must observe the context in which it is exercised. Brazil has become an increasingly powerful country, which is exerting growing influence over others. However, it is necessary to ask: which actors are influenced, in what ways, and in what areas? Therefore, discussions about power and influence cannot be separated from analyses of motives and values. While it can be accepted that countries naturally seek power, what kind of power are they seeking, for what purpose, and how do they intend to use it?

Historically, Brazilian foreign policy has moved between Americanism, which seeks closer proximity with (or subordination to) the major power, and globalism, a strategy aimed at diversifying the country's foreign relations, and retaining its 
independence from any specific world power or centre of the world economy (Pinheiro 2000). Under Fernando Henrique Cardoso's presidency, these two approaches resulted in more authentic foreign policy, with Brazilian diplomacy guided by efforts to re-establish the country's democratic and liberal credentials, and reposition it internationally as a trustworthy actor. In doing so, Brazil recognised and sought to adhere to the existing international norms, while reforming its domestic institutions to bring the country closer to 'modern liberal economics'.

The Lula presidency brought some important changes. The country achieved higher levels of economic growth and reduced extreme poverty as well as social inequalities. As mentioned, Brazil became the sixth largest economy in the world in 2012, and was considered free from hunger (a historical problem in the country which successive governments failed to address). Besides economic growth, an important reason for these outstanding results were the public policies designed to respond to the historical needs of a country with acute social problems: combating extreme poverty and hunger, increasing wages and formalising employment, and reducing social inequality. The Workers' Party governments were more connected with the problems faced by Brazil and its Southern partners; more empowered to deal with the contradictions of the Brazilian modernisation and development; better able to propose ways of meeting the typical challenges of developing and less developed countries (problems that are also increasing in the developed world); and better able to formulate appropriate and effective policies.

Moreover, those ideas and policies provided the ideological and strategic foundation for the reorganisation of Brazilian foreign policy in this period; and the public policies could be internationalised, disseminated, and transferred to other Southern countries, international organisations, and even developed countries. What we are saying is that Brazilian foreign policy could project Brazil as a social model that exposed the contradictions in international development paths, but also as an actor capable of proposing new solutions. Put differently, Brazil's 'autonomist understanding' and 'self-perception' as an actor capable of formulating and implementing a new socio-economic developmental model also emerged in its foreign policy. Brazil had the mix of technical and material capabilities it needed to build a particular but 'diffusible' economic development agenda, demonstrating the country's role in and commitment to global development and solidarity in the process.

The Brazilian development model under the Workers' Party combined liberal economic orthodoxy with state activism. The literature commonly refers to this as 'neo-developmentalism', or 'social developmentalism'11 (Bastos 2012). Economic orthodoxy was evident in the conservative macroeconomic policy inherited from the Cardoso government, notably the triad comprising 'inflation target', a floating exchange rate, and an aggressive policy for primary fiscal surplus. Sound macroeconomics and a stable currency were seen as essential foundations for higher levels of sustainable economic growth, based on domestic markets and domestic 11 Bastos (2012) distinguishes between 'new-developmentalism', a type of developmentalism aimed at
strengthening the export sector; and 'social-developmentalism', which incorporates distributive policies. 
consumption. ${ }^{12}$ On the other hand, the 'social developmentalism' was evident in policies aimed at promoting industrialisation and innovation, as well as social policies aimed at reducing inequalities and increasing family incomes. The novelty of this development agenda lay in its combination of two main elements: the return of an 'interventionist state', particularly with respect to industrialisation and technological innovation; and the centrality of social policies aimed at combating poverty and inequality as engines for national development (Erber 2011).

Policies to reduce poverty and inequality are fundamental to the achievement of fundamental human rights, but they are also instruments for an effective socioeconomic development strategy. In broad terms, the purpose of the Brazilian development strategy was to stimulate consumer spending by increasing formal employment, raising salaries and wages, and increasing pensions and other social welfare payments. ${ }^{13}$ This was linked to conditional income transfers policies as well as to efforts to create urban jobs and increase the incomes of rural workers. Thus, social inclusion and increased consumption stimulated the market and the domestic economy, producing a virtuous cycle of inclusive economic growth.

The social dimension of the Brazilian development project was represented by the 'Fome Zero' (Zero Hunger) Programme, which still exists today. It had two macro objectives, and incorporated specific public policies to achieve those objectives. The first objective was to provide the most vulnerable groupings with improved access to food. To achieve this goal, a range of policies were adopted, focusing on simulating supply and demand. Supply-side measures included agrarian development policies and the stimulation of family agriculture ${ }^{14}$ demand-side measures included the Food Acquisition Programme (PAA) and the School Feeding Programmes (PNAE).

The second strategic objective was to promote income generation, through programmes aimed at increasing family incomes as well as addressing extreme urban and rural poverty (which also increased the demand for food). In this sense, conditional income transfer programmes and policies to strengthen family agriculture are also essential, along with those to increase formal jobs wages.

These two objectives can be analysed via their primary public policies, which were 'exported' by the Brazilian government. The 'Bolsa Familia' programme (Family Allowance Programme) aimed at strengthening social rights involves the direct transfer of income to economically vulnerable families. At its peak, it reached 50 million Brazilians. Designed to reduce extreme poverty, it affects the economy as a whole, as it increases domestic consumption and impacts on health and education

\footnotetext{
12 The new-developmentalism would be precisely this coexistence between the positive elements of orthodoxy and heterodox economics, responding to a decline in neoliberalism and the rise of a new form of state-market relationship. It is not only a reaction to neoliberalism, but rather a new interpretation of the need for state intervention in the economy.

13 Between 2004 and 2015, specific laws were approved to guarantee a real increase in the minimum wage.

14 The most important programme in this regard was the National Programme for Strengthening Family Agriculture.
} 
indicators. ${ }^{15}$ 'Bolsa Familia' also relates to other income generation policies in Brazil, such as work qualification programmes, investments in productivity areas, solidarity economy initiatives, and access to microcredit. The Food Purchase Programme (PAA) and National School Feeding Programme (PNAE) are policies for stimulating small-scale family farming, reducing poverty in the countryside, and creating a sustainable small-scale productive system. The PAA is aimed at supporting agricultural production on family farms through the public purchase of food, transferring income to rural populations in the process. It also seeks to expand access to food by directing the production to people living in food insecurity, and to those served by the Brazilian social assistance system and other public facilities.

Adriana Aranha explains 'Fome Zero' and 'Bolsa Familia' as an 'intersectoral programme that establishes links between the supply of food from family agriculture and the demand for food from public programmes and facilities (e.g. school feeding, hospitals, free distribution of food, and prisons), and helps the formation of food stock' (Aranha 2010: 96).

To achieve all these goals, a sophisticated public and institutional structure was created. One essential aspect was the unification of social assistance data through the Single Social Assistance System. In 2004, the Brazilian government established the Ministry of Social Development (MDS) to organise and implement the policies related to 'Fome Zero' and especially 'Bolsa Familia'. In the same year, the General Coordination of Humanitarian Cooperation and the Fight against Hunger (CGFOME) was established in the Ministry of Foreign Affairs to serve as the international interface for Brazilian social policies. ${ }^{16}$ In 2006, 'Fome Zero' was transformed into a Law with the approval of the Organic Law of Food and Nutritional Security (LOSAN), which established the National System of Food and Nutrition Security (SISAN) as a normative framework for achieving food security. In 2010, the Federal Constitution was amended to acknowledge the right to food as a social right.

These initiatives produced significant results, and played a key role in the country's international insertion strategy. Some outcomes can be seen in the reduction of inequality-the transfers of income through specific social programmes were responsible for a significant drop in inequality. In addition, extreme poverty significantly decreased. For example, 'Bolsa Família' increased the average income of $29.2 \%$ of Brazilian families. Ultimately, Brazil succeeded in developing a wide-ranging social strategy that formed part of a broader model of inclusive growth-emanating from its own experience, and aligned with its specific needs and social constraints. It demonstrated its ability to think about and develop solutions, which allowed it to 'draw on concrete achievements to justify and legitimate leadership in international development, and not just rely on rhetoric or ideological

\footnotetext{
15 This programme has conditionalities linked to the enrolment of children in the public education system as well as the medical monitoring of families.

16 CGFOME deals more directly with emergencies and humanitarian crises. For example, it played an important role in the Brazilian humanitarian missions in Haiti after the earthquake and during the period of the MINUSTAH mandate. The abolition of CGFOME via ordinary legislation is symptomatic of the shifts in the Brazilian social development project and foreign policy after 2016.
} 
commonalities' (Dauvergne and Farias 2012). In other words, changing its conception and practice of development also changed the country's foreign policy, with notions of solidarity and international responsibility playing important thematic roles $^{17}$ (Carmody 2013; Vieira 2012).

Endogenous changes in the conception and formulation of an economic and social development strategy gave meaning to the Brazilian technical cooperation and other initiatives for the global diffusion of specific public policies, constructing a global agenda that mirrors this development model. In this sense, Brazilian foreign policy absorbed the domestic development pressures, repositioning Brazilian strategy on the need for a new global social and economic development policy. Besides the demand for stronger international representation-typically presented in demands for reform of the UN Security Council and other international institutions-Brazil also demanded recognition as an effective rising state, a country capable of developing fresh solutions based on a meaningful understanding of social development and distributive justice. In this regard, Brazil sought greater equilibrium with the leading global economies in order to ensure greater international representation through a global development agenda that mirrored its own development trajectory.

In terms of Hurrell's conception of the international insertion of a rising state, that considers the context in which power is exercised and the motives and values, Brazil proposed the internationalisation of a model of development based on its own experiences-a liberal macroeconomic matrix embedded with state engagement, as well as notions of social justice and equity. In the next section we will demonstrate that Brazil, via technical assistance in particular, exerted influence globally, reaching the developed Western countries, international organisations and its main partners from the Global South. But it was done in a very specific sense-in the building of a particular understanding on socioeconomic development, which materialises itself in specific public policies.

Still considering Hurrel's analysis, it is important to emphasise that Brazilian actions are not devoid of interests. We contend that Brazil sought the legitimisation of a global development agenda that reflected both material and ideational interests related to the historical demands of peripheral states. In that regard, Brazil's pursuit of prestige and recognition would derive from attracting others and reforming international norms according to its particular experience in tackling social inequalities through public policymaking. As an upshot of these international practices, Brazil also built an international network of partner countries which absorbed Brazilian social policy technologies, hence creating a new market for Brazilian institutions and services. In sum, this section has shown that Brazil built its rising state status through successfully leveraging domestic public policies as foreign policy assets. Next, we focus on how Brazil has effectively developed mechanisms for the diffusion and transfers of these policies.

\footnotetext{
17 For instance, in a speech at Davos in 2003, Lula proposed the creation of a 'Global Fund to Fight Hunger', and a 'World Committee to Fight Hunger'. The following year, in negotiations with the presidents of France and Chile and the UN Secretary-General, they launched the 'Global Action Against Hunger and Poverty' (United Nations World Summit for Action Against Hunger 2004).
} 


\section{The diffusion and transfer of the Brazilian development model: rebuilding the understandings of social development}

Socioeconomic changes in some developing countries have opened new spaces for changes in international relations. Opportunities have been created for greater assertiveness, and new demands for global change. Institutions governing the international political economy and international cooperation are being pressured by changes in the developmental interests of recipient countries as well as of emerging donors (Harman and Williams 2014). Thus Quadir (2013: 2) notes that

the successful transition by some Southern economies from aid recipient to economic powerhouse is opening space for them to assume greater responsibility for promoting development based on the complex and often misunderstood realities of the struggles for sustainable human development in the global South.

In this context, Brazil significantly expanded its international presence and its international cooperation priorities. A prominent feature of its reinvigorated international campaign was the transfer of effective and well-evaluated ${ }^{18}$ public policies, and social technologies to recipient countries that could promote local development and contribute to autonomous development. Brazilian cooperation was guided by the notion of solidarity, emphasised in policymakers' speeches but also evident in the form and content of international cooperation. Brazil also sought to define a cooperation agenda focused on practices that could be exchanged between similar realities, and could respond to partners' development interests.

In other words, space and opportunities opened for the diffusion and transfer of Brazil's development model, including its social assistance strategy, and the public policies and practices that had succeeded in reducing poverty and inequality and improving health and education. Therefore, the essence of Brazilian international initiatives was not the transfer of material resources, but the 'export' of good practices and solutions that had worked in Brazil, 'transferring its knowledge gained from successful social and economic development experiences' (Dauvergne and Farias 2012: 909). Some scholars argue that Brazil did not intend to become a major financial donor, but rather to export sound public policies to other developing countries. This is consistent with the Brazilian economic condition, which despite being a large economy still lives with strong budget restrictions. But this strategy also had a political aspect, namely the promotion of Brazilian model of social development, directing it to the intended priority of building new international developmental norms (Ayllon and Leite 2010; Milhorance 2013; Constantine and Shakland 2017).

\footnotetext{
18 The Brazilian development model and policies during the period under analysis have been judged to be successful by numerous international organisations, including the World Bank, the UNDP, UNCTAD and ECLAC, as well as various non-governmental organisations. The World Bank has also recognised the importance of Brazilian policies in reducing poverty and inequality, pointing to the fact that these policies have helped to break the cycle of poverty transmission in the country. See http://www.world bank.org/pt/news/opinion/2013/11/04/bolsa-familia-Brazil-quiet-revolution (last accessed on 10 May 2021).
} 
International cooperation and other forms of diffusion and transfer of social policies for income transfer, hunger and poverty relief, despite not attaining high budgets, have symbolic aspects and target a vital socio-strategic dimensions of Brazilian foreign policy. The humanitarian aspects of fighting poverty and hunger, and the Brazilian social agenda gained prominence in its foreign policy through the creation of institutions aimed at diffusing and transferring the Brazilian policies throughout the world (Caixeta and Suyama 2015). In this sense, Brazil was assuming the costs of a more relevant position internationally, while presenting itself with norm-setting credentials.

In this way, Brazil's socioeconomic development model not only played a vital role domestically, but also became a central feature of its global strategy. Brazil worked to build a 'global social agenda' and to disseminate Brazilian best practice, thereby proposing new international norms for social development-especially its conditional income transfer policy and the policies to fight hunger and poverty that have received international recognition, and have been incorporated into various international diffusion and transfer initiatives.

It is important to highlight at this juncture that our claim that Brazil has gained status recognition through international activism does not apply to every single area of Brazilian foreign policy engagements, such as, for example, the historical demand for the reform of the UN's Security Council. During the Lula and Dilma administrations, other demands emerged, such as the reform of the IMF, and Brazil presented itself, not always successfully, as an articulator of major international political contentions. Although we acknowledge that these were areas with limited gains, it can hardly be said that these would be the most relevant and critical Brazilian international demands during the Workers Party's administration. The focus of the article is on Brazil's normative impact with regards to international development policies and our claim is that significant innovations were incorporated to international frameworks and states' practices due to Brazil's diplomatic activism.

Brazil became a global reference on social development and a benchmark for traditional donors, especially the UK Department for International Development (DFID), international organisations and some relevant non-governmental organisations. ${ }^{19}$ In the same sense, Brazil relied on globally relevant international organisations such as the World Bank, ${ }^{20}$ the Food and Agriculture Programme (FAO), the

\footnotetext{
19 The UN document 'Report of the Secretary-General: Promotion of South-South cooperation for development: a thirty-year perspective' (Doc A/64/504, 2009) highlights Brazilian initiatives as successful. FAO and WFP were inspired by the programme. In its 2015 Human Development Report, the UNDP states that 'the programme was essential for the reduction of multidimensional poverty in the country by promoting access to health, education and social assistance'. Moreover, organisations as ActionAid and Oxfam recognised 'Hunger Zero' as the most important initiative to reduce hunger and poverty in the world (Fraundorfer 2015).

20 The World Bank and UNDP sought to incorporate the Brazilian model as a reference in their actions, and also provide technical assistance to countries to adopt similar policies or improve the existing ones. See 'Brasil ajuda o mundo a reduzir a miséria', available at http://www.ipea.gov.br/desafios/index.php? option=com_content $\&$ view=article $\& i d=2946$ : catid=28\&Itemid=23 (last accessed on 10 May, 2021). With the assistance of the World Bank and other multilateral agencies such as the Inter-American Development Bank (IDB), officials from numerous countries have been trained and absorbed knowledge on these policies. See 'Brasil exporta Bolsa Família para 11 países', available at http://ultimosegundo.ig.
} 
United Nations Development Programme (UNDP), and the World Food Programme $(\mathrm{WFP})^{21}$ to assist with the transfer and diffusion of its policies. Brazil also worked to establish new institutions tasked with structuring and spreading social policies for human development - the International Policy Centre for Inclusive Growth (IPCIG), the WFP Centre of Excellence against Hunger, and the Brazil Learning Initiative for a World without Poverty (WWP).

As noted earlier, Fome Zero, Bolsa Família and PAA formed part of a broader strategy and macroeconomic agenda to increase national income and foster development. Brazil's most prominent public policies for social development have been diffused and transferred, supported by established international organisations. These organisations not only contributed to the diffusion and transfer of Brazilian policies, but also incorporated the Brazilian development model and policies into their practices and projects, learning from Brazil and incorporating its practices into their routines.

According to the World Bank, 52 countries have emulated the Bolsa Família model in the course of building their own income transfer programmes. Between 2011 and 2015, the Brazilian Ministry of Social Development (MDS) received 406 delegations from 97 countries interested in gaining a better understanding of Bolsa Família functioning. In the same period, Ministry representatives participated in more than 100 international events about policies for income transfer, presenting and disseminating the Brazilian programme. ${ }^{22}$ Regarding food security and agrarian development policies, high-level representatives from 70 countries have learnt from Brazil's experience and interacted with Brazilian policymakers. ${ }^{23}$

In turn, Brazil and FAO have developed a fruitful collaboration under the rubric of the Programme of Brazil-FAO International Cooperation. The most important initiative under this programme is the Purchase from Africans for Africa (PAA Africa), undertaken in partnership with the WFP and DFID, and inspired by the Brazilian Food Purchase Programme. ${ }^{24}$ Brazil and the FAO have also conducted

\footnotetext{
Footnote 20 (continued)

com.br/brasil/brasil-exporta-bolsa-familia-para-11-paises/n1237788315919.html (last accessed on 10 May, 2021).

21 The WFP is a humanitarian agency that provides food aid in emergency situations.

22 'Modelo do Bolsa Família foi “exportado" para 52 países', available at http://www.brasil.gov.br/cidad ania-e-justica/2016/01/modelo-do-bolsa-familia-foi-exportado-para-52-paises (last accessed on 18 April 2019).

23 'Brazil's Contribution to a World Free of Poverty', available at http://www.worldbank.org/en/news/ opinion/2014/03/24/brazil-contribution-world-without-poverty (last accessed on 10 May, 2021).

24 'Besides helping to supplement the diets of hungry people, the project is designed to strengthen local food markets, ultimately helping to improve food security, and preventing future food crises. Food purchase programmes provide a new perspective on agricultural development and food interventions. The traditional emphasis on technology transfer, aid and assistance is replaced with an effort to secure the social and institutional conditions required to ensure that populations at risk of food insecurity have access to quality food which is generated through the participation of smallholders in the market.' In 'Brazil to fund food purchasing in five African countries', available at http://www.fao.org/news/story/en/ item/123551/icode/ (last accessed on 10 May, 2021).
} 
other experiments aimed at bringing the Brazilian experience of school feeding and family farming to other countries and regions ${ }^{25}$ (Maluf et al. 2014).

Furthermore, Brazilian social development policy and international cooperation practices, in partnership with other actors, have led to the consolidation of new political arrangements and new structures for knowledge production to ensure greater capillarity and depth in the diffusion and transfer of its social policies. After a collaboration agreement with UNDP in 2004, the International Policy Centre for Inclusive Growth (IPC-IG), established in 2002 as the International Poverty Centre, moved to Brasília becoming the first UN body based in Brazil. ${ }^{26}$ It manages a global forum for stimulating South-South dialogue about innovative development policies. The Centre has played a crucial role in disseminating knowledge about Bolsa Família and other anti-hunger policies, and promoting their global diffusion. ${ }^{27}$

One of the Centre's most highlighted activities has been the development of the Africa-Brazil Cooperation Programme on Social Development. Financed by DFID, and implemented by the MDS and the IPC-IG, its purpose is to transfer specific knowledge of Bolsa Família and other Brazilian social protection systems to African countries $^{28}$ (Fraundorfer 2013). This project forms part of a series of initiatives developed by the Brazilian government and international organisations to disseminate Brazilian social programmes. As explained by Leite et al. (2015), 'the promotion of Bolsa Família abroad is seen as having been driven by requests that arose exponentially because of the programme's allegedly proven success, rich documentation in international literature and its dissemination by international organisations'.

Another important Brazilian initiative undertaken in tandem with the World Bank and IPC-IG is the Brazil Learning Initiative for a World Without Poverty (WWP). As described on the website, the WWP is an interinstitutional partnership between the Brazilian Government (through the Ministry of Social Development and the Institute for Applied Economic Research), the mentioned International Policy Centre for Inclusive Growth and the World Bank Group. ${ }^{29}$ Since the beginning of activities in 2013, the WWP has been dedicated to the sharing of technical knowledge to promote social development, productive inclusion, and overcoming poverty, through the documentation and dissemination of successful policies, especially those to

\footnotetext{
25 The agreements entitled 'Strengthening School Feeding Programs in African Countries' and 'Strengthening School Meal Programs under the Hunger Free Latin America and the Caribbean 2025 Initiative' are examples of initiatives aimed at the development of family agriculture together with the nutritional improvement of children. See 'Brasil e FAO estreitam cooperação para erradicar a fome', available at https://nacoesunidas.org/brasil-e-fao-estreitam-cooperacao-para-erradicar-a-fome/ (last accessed on 18 April 2019).

${ }^{26}$ In 2009, a new Memorandum of Understanding was signed with the UNDP to enhance the Centre's role.

27 Some publications of the Centre that reported the effects of the programme significantly impacted the international relevance of the IPC-IG, causing it to become increasingly involved in international knowledge transfer activities for the implementation of conditioned income transfer policies and the Brazilian experience in other countries.

28 The countries that benefited from the project were Ghana, Guinea-Bissau, Mozambique, Nigeria, South Africa and Zambia.

29 Available at http://wwp.org.br/en/ (last accessed on 10 May, 2021).
} 
combat poverty adopted by Brazil, and the holding of working meetings with countries' representatives interested in learning from the Brazilian initiatives. ${ }^{30}$

In other words, its main objective is to increase the global impact of the social policies implemented in Brazil, facilitating their diffusion and the dissemination of the results achieved. Sharing the content and modus operandi of Brazilian public policies for countries facing similar problems is a clear way of disseminating the Brazilian model of social development and combating poverty.

Another Brazilian initiative for institutionalising its public policies was the WFP Centre of Excellence against Hunger. It is a partnership between Brazilian government and the WFP. The Centre 'draws on Brazilian experience to share knowledge and policy innovations among developing countries. Primarily focused on linking school meal systems to local agriculture, it provides technical assistance to national governments to design, improve, expand, and eventually run their programs' ${ }^{31}$ Specifically, the centre has played a crucial role in transferring the Brazilian Food Acquisition Programme to African countries through the Purchase from Africans for Africa (PAA Africa) programme. Five countries-Ethiopia, Malawi, Mozambique, Niger and Senegal-were initially included in the programme. The goal was the same as that pursued in Brazil, namely to strengthen smallholder production, improve food security, combat hunger, and generate income for rural populations. ${ }^{32}$

PAA Africa and the WFP Centre of Excellence against Hunger reflect a history of initiatives implemented by the Brazilian government in partnership with other organisations. In 2010, the Brazil-Africa Dialogue on Food Security, the Fight Against Hunger, and Rural Development was launched with the participation of more than 45 African countries as well as East Timor. The meeting resulted in a document in which the Brazilian government committed itself to deepening cooperation on food security with African countries. ${ }^{33}$ And in 2005, Brazil and Guatemala launched the Hunger-Free Latin America and Caribbean Initiative. ${ }^{34}$ These initiatives highlight the role of the WFP and FAO in spreading Brazil's food security model to Latin America as well as Africa. In 2011, the MDS, in cooperation with the FAO, launched an agenda for the Support for National and Sub-regional Strategies for Food and Nutrition Security and for Overcoming Poverty in Latin American and Caribbean Countries, and in 2012 it launched the Zero Hunger Challenge at the Rio+20 Conference.

Brazil has transferred part of the public policies that encompass its socio-economic development project through international technical cooperation and has worked to reframe some international practices related to international development

\footnotetext{
${ }_{30}$ For instance, in 2014, the WWP organised the South-South Learning Forum on Social Protection and Labor Systems with representatives from 70 countries.

31 See it at https://www.wfp.org/centre-of-excellence-against-hunger (last accessed on 10 May, 2021).

32 The WFP already had a purchase project, the 'Purchase for Progress' (P4P). The Cooperation with Brazil gave more impetus to the initiative.

33 Besides the implementation of PAA Pilot Projects in 10 African countries, the event led to the creation of the Centre for Strategic Studies and Training in Tropical Agriculture of Embrapa (Fraundorfer 2015).

${ }^{34}$ See it at http://www.fao.org/americas/prioridades/alc-sin-hambre/en/ (last accessed on 10 May, 2021).
} 
and for the construction of norms and institutions that consolidate and disseminate a reformed international development model. Thus, through these initiatives, Brazil achieved a significant degree of international relevance as a particular kind of rulemaker, helping in the consolidation of an innovative perspective of development, which mirror the Brazilian trajectory and its practices and are aligned with similar developmental challenges faced by the periphery.

\section{Conclusions}

Besides regional cooperation, rising states are increasingly using multilateral institutions to influence the conduct of other states, and encourage international patterns of behaviour that are closer to their interests. The power of those countries is related to their ability to influence the international norms and standards that determine the global distribution of wealth, prestige and power. In this article, we have sought to show that rising states can utilise the diffusion and transfer of social policies to affect international politics and participate in the process of building international norms and institutions. In other words, some states on the periphery can make use of different power capabilities and alternative forms of socialisation to establish themselves as rising states, and create international norms that are more reflective of their self-perceptions, interests and demands, as well as collaborating with its partners.

More specifically, we have presented the diffusion and transfer of the social policies at the heart of Brazil's development model, notably its conditional income transfer programmes and the agricultural development policies aimed at combating hunger and improving the incomes of rural populations - these policies were obviously inserted in a broader national development model and were supported by a period of economic growth. Brazil has been assisted by established international organisations, which have endorsed its policies, and helped to disseminate them. The incorporation of Brazilian policies and practices signals an important contribution of the country to the redesign of international development practices and norms. However, it has also established new institutions aimed at disseminating its policies, consolidating a development agenda, and reflecting and promoting the interests of the periphery. These include the IPC-IG, the WFP Centre of Excellence against Hunger, and the Brazil Learning Initiative for a World without Poverty.

Rising states have different capabilities, and different means of gaining power. Brazil does not have the material capabilities to challenge the established international norms and it has never been a country that openly contests the international order. However, under the Worker's Party governments it positioned itself as an autonomous political actor engaged in a process of reforming global norms and patterns of behaviour that affect the ability to define the most appropriate development policies not only for their own sake but as a means of advancing its own interests and those of its partners on the global periphery. Indeed, Brazil proved itself capable of proposing international norms that represented Brazilian identity, and expressed the peculiarities of its developmental trajectory. Therefore, we have argued in this article that, through the diffusion and transfer of its innovative model of social 
development, Brazil played the role of rising power on the global stage by offering solutions to dilemmas typical of peripheral modernisation.

However, it is important to note that alternation of power in democratic systems can profoundly transform worldviews, interests and strategies. The election of Jair Bolsonaro in 2018 has dramatically changed Brazilian domestic politics as well as the ideas and the government's policy agendas for economic, social and environmental development. Relevant public policies which were central to Brazil's attempts to build its international reputation and leverage soft power during Lula's and Rousseff's administrations have been fundamentally changed, particularly concerning social protection, human rights and environmental issues.

Brazil's political and institutional achievements discussed in this article are currently been fundamentally reversed with clear implications in terms of the country's previous reputation as a rising power. No change has been more profound than the change in its international relations. Under Bolsonaro, Brazil moved from an independent foreign policy, founded on principles of multilateralism and South-South cooperation, to a strategy of automatic alignment with the United States' Donald Trump and the establishment of close relations with a hand-full of likeminded governments, sharing similar ultra-conservative nationalist values and an anti-globalist ideology.

The poor management of the COVID-19 pandemic, in open opposition to the World Health Organization's scientific guidelines, has further undermined the perception of Brazil as a global leader and reliable multilateral player. Similarly, international outrage following the government's downplaying of devastating fires in the Amazon rainforest in 2019/2020 and its lack of commitment to tackling climate change, have also contributed to radically reversing Brazil's international image from a rising power to an politically weakened and increasingly isolated pariah. ${ }^{35}$

Acknowledgements The authors are grateful to the University of Birmingham, through its Brazil Visiting Fellow scheme, for hosting and funding Dr. Henrique Menezes as a visiting research fellow, between November 2016 and January 2017. We are also thankful to the anonymous reviewers and the editors for their constructive comments on the article

\section{References}

Abbott, Kenneth and Duncan Sinidal (1998) 'Why states act through formal international organizations', Journal of Conflict Resolution 42(1): 3-32.

Aranha, A. (2010) 'Fome Zero: um projeto transformado em estratégia de governo', in José Graziano, M. E. Grossi and C. G. França, eds, Fome Zero: a experiência brasileira, Brasília: MDA.

\footnotetext{
35 In a speech delivered to Brazilian diplomat graduates, Bolsonaro's Foreign Minister, Ernesto Araujo, proudly admitted Brazil's current status as an international pariah. He argued that 'today Brazil speaks of freedom across the world. If this makes us an international pariah, so be it' (free translation by the authors from the original in Portuguese). Speech delivered on 22 October, 2020, in Brasilia, see http:// www.itamaraty.gov.br/pt-BR/discursos-artigos-e-entrevistas-categoria/ministro-das-relacoes-exter iores-discursos/21888-discurso-do-ministro-das-relacoes-exteriores-ernesto-araujo-na-formatura-daturma-joao-cabral-de-melo-neto-2019-2020-do-instituto-rio-branco-brasilia-22-de-outubro-de-2020 (last accessed on 1 November, 2020).
} 
Ayllon, B. and Iara Leite (2010) 'La cooperación Sur-Sur de Brasil: Instrumento de política exterior y/o manifestáción de solidariedad internacional?' [Brazil's South-South cooperation: Foreign policy instrument and / or manifestation of international solidarity], Mural Internacional 1: $20-32$.

Bastos, P. (2012) 'A economia política do novo-desenvolvimentismo e do social desenvolvimentismo' [The political economy of neo-developmentalism and the social developmentalism], Economia $e$ Sociedade 21: 779-810.

Breuning, Marijke (2011) Role Theory Research in International Relations: State of the Art and Blind Spots. In Sebastian Harnisch, Cornelia Frank and HW Maull, eds, Role Theory in International Relations: Approaches and Analyses, 16-35, London: Routledge.

Caixeta, Marina and Bianca Suyama (2015) 'A Cooperação Sul-Sul em Proteção Social' [The SouthSouth Cooperation for social protection], Observatório o Brasil e o Sul 1: 1-14.

Carmody, Pádraig (2013) 'Globalising solidarity or legitimating accumulation? Brazilian strategies and interest in Africa', Irish Studies in International Affairs 24: 81-99.

Constantine, Jennifer and Alex Shankland (2017) 'From Policy Transfer to Mutual Learning? Political Recognition, Power and Process in the Emerging Landscape of International Development Cooperation', Novos Estudos CEBRAP 36(1): 99-122.

Dauvergne, Peter and Déborah Farias (2012) 'The rise of Brazil as a global development power', Third World Quartely 33(5): 903-17.

Diez, Thomas (2005) 'Constructing the Self and Changing Others: Reconsidering "Normative Power Europe"”, Millennium - Journal of International Studies 33(3): 613-36.

Dobbin, Frank, Beth Simmons and Geoffrey Garreth (2007) 'The Global Diffusion of Public Policies: Social Construction, Coercion, Competition, or Learning?', Annual Review of Sociology 33: $449-72$.

Dolowitz, David and David Marsh (2000) 'Learning from Abroad: The Role of Policy Transfer in Contemporary Policy-Making', Governance: International Journal of Policy and Administration 13(1): $5-24$.

Drezner, Daniel (2001) 'Globalization and Policy Convergence', International Studies Review 3(1): 53-78.

Elkins, Zachary, Andrew Guzman and Beth Simmons (2006) 'Competing for Capital: The Diffusion of Bilateral Investment Treaties, 1960-2000', International Organization 60(4): 811-46.

Erber, Fábio. (2011) 'As Convenções de Desenvolvimento no Governo Lula: um ensaio de economia política' [The Development Conventions during Lula's government: an essay on political economy], Revista de Economia Política 31(1): 31-55.

Fraundorfer, Markus (2013) 'Zero Hunger for the World - Brazil's Global Diffusion of its Zero Hunger Strategy', Austral: Brazilian journal of strategy \& international relations 2(4): 91-116.

Fraundorfer, Markus. (2015) Brazil's Emerging Role in Global Governance: health, food security and Bioenergy, Palgrave Macmillan.

Gardini, Gian. (2016) 'Brazil: What Rise of What Power?', Bulletin of Latin American Research 35(1): $5-19$.

Goldstein, Judith and Robert Keohane, eds (1993) Ideas and Foreign Policy: Beliefs, Institutions, and Political Change, Ithaca; London: Cornell University Press.

Harman, Sophie and David Williams (2014) 'International Development in Transition', International Affairs 90(4): 925-41.

Holsti, Kalevi J. (1970) 'National Role Conceptions in the Study of Foreign Policy', International Studies Quarterly 14(3): 233-309.

Holzinger, Katharina and Christoph Knill (2005) 'Causes and Conditions of cross-national policy convergence', Journal of European Public Policy 12(5): 775-96.

Hurrell, Andrew (2010) 'Brazil: what kind of rising state in what kind of institutional order?', in Alan Alexandroff and Andrew Cooper, eds, Rising States, Rising Institutions: challenges for global governance, Centre for International Governance Innovation.

Jackson, Robert (1993) 'The Weight of Ideas in Decolonization: Normative Change in International Relations', in Judith Goldstein and Robert Keohane, eds, Ideas and Foreign Policy: Beliefs, Institutions, and Political Change, 111-38, Ithaca and London: Cornell University Press.

Kahler, Miles (2013) 'Rising Power and Global Governance: negotiating change in resiliente status quo', International Affairs 89(3): 711-29.

Landolt, Luara (2004) '(Mis)Constructing the Third World? Constructivist Analysis of Norm Diffusion', Third World Quarterly 25(3): 579-91. 
Leite, Iara, Melissa Pomeroy and Bianca Suyama (2015) 'Brazilian South-South Development Cooperation: the Case of the Ministry of Social Development In Africa', Journal of International Development 27(8): 1446-61.

Maluf, Renato, Mariana Santarelli and Veruska Prado (2014) 'A cooperação brasileira em segurança alimentar e nutricional: determinantes e desafios presentes na construção da agenda internacional' [The Brazilian cooperation in food and nutritional security: determinants and challenges presents in the building of the international agenda], CERESAN Texto para Discussão 3.

Marsh, David and Jason Sharman. (2009) 'Policy Diffusion and Policy Transfer', Policy Studies 30(3): 269-88.

Milhorance, Carolina. (2013) 'A política de cooperação do Brasil com a África Subsaariana no setor rural: transferência e inovação na difusão de políticas públicas' [The Brazilian cooperation policy with sub-Saharan Africa in the rural sector: transfer and innovation in the diffusion of public policies], Revista Brasileira de Política Internacional 56(2): 5-22.

Morin, Jean-Frédéric and Edward Gold (2015) 'An Integrated Model of Legal Transplantation: The Diffusion of Intellectual Property Law in Developing Countries', International Studies Quarterly 58: 781-92.

Murphy, Craig (2005) Global Institutions, Marginalization, and Development, Routledge.

Nayyar, Deepak (2016) 'BRICS, Developing Countries and Global Governance', Third World Quarterly 37: 575-91.

Nel, Philip. (2010) 'Redistribution and Recognition: what emerging regional powers want', Review of International Studies 36: 951-74.

Nel, Philip (2014) 'Rising powers, global capitalism and liberal global governance: A historical materialist account of the BRICs challenge', European Journal of International Relations 20(4): 912-38.

Pinheiro, Leticia. (2000) 'Traídos pelo Desejo: Um Ensaio sobre a Teoria e a Prática da Política Externa Brasileira Contemporânea' [Betrayed by Desire: An Essay on Theory and Practice of Contemporary Brazilian Foreign Policy], Contexto Internacional 22(2): 305-35.

Quadir, Fahimul (2013) 'Rising Donors and the New Narrative of "South-South" Cooperation: what prospects for changing the landscape of development assistance programmes?', Third World Quarterly 34(2): 321-38.

Stephen, Matthew (2014) 'States, Norms and Power: emerging power and Global Order', Millennium 42(3): 888-96.

Towns, Ann (2012) 'Norms and Social Hierarchies: understanding international policy diffusion "from below", International Organization 66: 179-209.

Vieira, Marco (2012) 'Rising States and Distributive Justice: Reforming International Order in the Twenty-First Century', Global Society 26(3): 311-29.

Xiaoyu, Pu (2012) 'Socialisation as a Two-way Process: emerging powers and the diffusion of international norms’, Chinese Journal of International Politics 5: 241-367.

Publisher's Note Springer Nature remains neutral with regard to jurisdictional claims in published maps and institutional affiliations.

Henrique Menezes is Associate Professor in the Department of International Relations at the Federal University of Paraiba, Brazil. He was awarded a PhD in Political Science from the State University of Campinas, Brazil. His research focuses on international political economy, international cooperation, intellectual property rights, innovation and sustainable development. He has published peer-reviewed articles in academic journals, and has recently published three books on the sustainable development goals, the US international political economy, and intellectual property, health and development.

Marco Vieira is Associate Professor in the Department of Political Science and International Studies at the University of Birmingham. He was awarded a PhD in International Relations from the Department of International Relations at the London School of Economics and Political Science (LSE). His research focuses on the rising influence and identity of 'Southern powers', especially South Africa, India and Brazil. He has published various peer-reviewed articles in internationally recognised academic journals, such as Millennium Review of International Studies Foreign Policy Analysis International Studies Review Environmental Politics Global Governance Global Society, among others. He is co-author of the book The South in World Politics. 